\title{
The Logic of Location: Malaria Research in Colonial India, Darjeeling and Duars, 1900-30
}

\author{
NANDINI BHATTACHARYA*
}

\begin{abstract}
This article explores the scientific and entrepreneurial incentives for malaria research in the tea plantations of north Bengal in colonial India. In the process it highlights how the logic of 'location' emerged as the central trope through which medical experts, as well as colonial administrators and planters, defined malaria research in the region. The paper argues that the 'local' emerged as both a prerequisite of colonial governance as well as a significant component of malaria research in the field. Despite the ambiguities that such a project entailed, tropical medicine was enriched from a diverse understanding of local ecology, habitation, and structural modes of production. Nevertheless, the locality itself did not benefit from anti-malarial policy undertaken either by medical experts or the colonial state. This article suggests that there was a disjuncture between 'tropical medicine' and its 'field' that could not be accommodated within the colonial plantation system.
\end{abstract}

Keywords: Tropical Medicine; Malaria; Prophylaxis; Anti-Malarial Sanitation; Tropical Aggregation of Labour; Immunity; Race; Plantation Economy; Anopheles; Species Sanitation; Local Knowledge; Quinisation; S.R. Christophers.

\section{Introduction}

Malaria in colonial India has been linked to the agencies of modernisation. The problematic of colonial 'development' leading to the spread of malaria has been located in terms of disease and political economy. Sheldon Watts and Ira Klein have linked the increase and spread of malaria in colonial India to the rapid commercialisation of agriculture, deforestation, expansion of the railways, construction of embankments, as well as urbanisation, consequent on the monetisation of the colonial Indian economy in the nineteenth century. ${ }^{1}$ Borrowing from twentieth-century nationalist critiques, historians

(C) Nandini Bhattacharya, 2011.

\footnotetext{
*Nandini Bhattacharya, Wellcome Research Fellow, Centre for Urban History, School of Historical Studies, University of Leicester, Marc Fitch House, 3-5 Salisbury Road, Leicester LE1 7QR, UK. Email: nb177@le.ac.uk
}

\author{
${ }^{1}$ For instance, see Sheldon Watts, 'British \\ Development Policies and Malaria in India \\ 1897-c.1929', Past and Present 165 (1999), 141-81; \\ Ira Klein, 'Death in India: 1871-1921', Journal of \\ Asian Studies, 32 (1973), 639-59.
}


have identified British development policies as the cause of malaria in colonial Bengal, but have not critically analysed the medical debates around malaria and development in colonial Bengal. ${ }^{2}$ Klein has studied the relationship between ecology, environmentalism and malaria in colonial India and has argued that there was a relative decrease in malaria mortality in Bengal in the mid-twenties, and attributed it to the rise in immunity in the surviving populations in the worst-affected districts of Bengal. The links between malaria and development are, however, tortuous: Randall Packard has pointed out that anti-malarial policy and the 'development' that followed in the Transvaal benefited large plantation owners and marginalised both small white farmers and African peasants. $^{3}$

Less debated have been the trajectories of malaria research, anti-malarial policy, and the role of the colonial state and private entrepreneurship in formulating and directing anti-malarial programmes. It is important to do so because malaria research was conducted at important sites of colonial economy, such as plantations, port cities, and cantonments, where malaria threatened economic or military activities. Sustained anti-malarial initiatives were undertaken in the rubber estates in Malaya, in the coffee plantations of Ceylon, the large tea plantations of Assam, and at the eastern frontier during the Second World War. ${ }^{4}$ The Liverpool School of Tropical Medicine was supported almost exclusively by entrepreneurial patronage from planters and miners in Southeast Asia and West Africa. This paper explores the incentives for medical research in a tropical colony by analysing malaria research in one such area, the tea plantations of north Bengal. It demonstrates the duality of locality in colonial malaria research. The site of research assumed significance as a primary factor both in the identification of the causation of disease, as well as in the economic concerns of colonialism. Yet, this focus on specific localities in terms of research and economic activities did not extend to sustained implementation of anti-malarial policies at those very sites.

The logic of location had wide acceptance within colonial medical and official discourse. Historians have established that in the nineteenth century, British Indian medical officers believed that local conditions in India contributed to a unique disease zone, to the extent that many rejected bacteriological explanations for cholera. ${ }^{5}$ The logic of location transcended miasmatic theories of fever and was appropriated within the framework of tropical medicine, including malaria research in the twentieth century and informed anti-malarial policy.

\footnotetext{
${ }^{2}$ Arabinda Samanta, Malarial Fever in Colonial Bengal: Social History of an Epidemic, 1820-1939 (Kolkata: Firma KLM, 2002); Sandeep Sinha, Public Health Policy and the Indian Public: Bengal 1850-1920 (Calcutta: Vision Publications, 1998).

${ }^{3}$ Randall Packard, 'Malaria Blocks Development Revisited: The Role of Disease in the History of Agricultural Development in the Eastern and Northern Transvaal Lowveld, 1890-1960', Journal of Southern African Studies, 27 (2001), 591-612.

${ }^{4}$ Lenore Manderson, Sickness and the State: Health and Illness in Colonial Malaya, 1870-1940, (Cambridge: Cambridge University Press, 1996);
}

K.T. Silva, 'Malaria Eradication as a Legacy of Colonial Discourse: The Case of Sri Lanka', Parassitologia, 36 (1994), 149-63; Philip Curtin, 'Medical Knowledge and Urban Planning in Tropical Africa', American Historical Review, 90, 3 (1985), 594-613.

${ }^{5}$ J.D. Isaacs, 'D.D. Cunningham and the Aetiology of Cholera in British India, 1869-1897', Medical History, 42 (1998), 279-305; Mark Harrison, 'A Question of Locality: The Identity of Cholera in British India, 1860-1890', in David Arnold, (ed.), Warm Climates and Western Medicine (Amsterdam: Rodopi, 1996), 133-59. 


\section{The Logic of Location}

This logic also became significant in the context of epidemiology. The explorations of the relationships between vector control and transmission among the mosquito vector, the parasite, the environment, and the behaviour of human carriers in particular, privileged malaria studies based at the sites of the occurrence of the disease in the 'field', a term used by scientists and anthropologists alike. The influence of environmental factors on tropical medicine was not just limited to malaria. Research on trypanosomiasis in Africa also appropriated a complexity of variables including ecology, insect vector, parasite, and human and animal infection in the inter-war years. ${ }^{6}$ The emphasis on environment and its links with malaria was retained long after the discovery of the insect vector of the malaria parasite, and medical research linked fevers to localities in fresh terms. 'Species sanitation', a term coined by the Dutch researcher N.H. Swellengrebel in 1911 to link carrier anopheline species with specific habitats, enriched the cognitive connection between ecology and malaria research. ${ }^{7}$ In India, this cognitive link had particular resonance, as British Indian sanitary theories had long favoured the uniqueness of location in medical discourse, particularly with respect to cholera. ${ }^{8}$ The logic of 'location' appeared in multifarious forms in malaria research. These included local vectors, ecology, demography, race, and culture. As this paper will show, malaria research in the Darjeeling hills was imbued with the multiple and ambiguous identifications of the local.

Yet, paradoxically perhaps, malaria research was an international project. In the years following Ronald Ross's discovery of the insect-vector factor in malaria (1897), carefully selected sites became locations for intensive anti-malarial activity in many parts of the world. In Italy, a generation of malariologists established research and conducted anti-malarial sanitation. ${ }^{9}$ After the First World War, the League of Nation's fledgling Health Committee conducted a series of malaria surveys in several Mediterranean and Baltic countries, formerly theatres of the War, where malaria mortality had been enormous. Within the British Empire, malaria researchers focused intensely on specific sites, especially those that were of strategic or economic interest in Africa, India, Ceylon, and Malaya between 1900 and 1930. The London and Liverpool Schools of Tropical Medicine provided institutional support to many researchers who travelled to many parts of the tropical world, and who exchanged research and debated anti-malarial policies and strategy vigorously in international conferences and medical journals. Malaria research in India was a part of the international research agenda, often borrowing from, as well as contributing to contemporary international debates. When J.A. Sinton compiled a bibliography of malaria research in India, he filled two hundred pages with more than two thousand items from scientific and medical journals. ${ }^{10}$ As we shall see, every local anti-malaria project in India borrowed ideas from contemporary

\footnotetext{
${ }^{6}$ See Helen Tilley, 'Ecologies of Complexity: Tropical Environments, African Trypanosomiasis, and the Science of Disease Control Strategies in British Colonial Africa, 1900-1940', Osiris, 19 (2004), 21-38.

${ }^{7}$ D.J. Bradley, 'Watson, Swellengrebel and Species Sanitation: Environmental and Ecological Aspects', Parassitologia, 36, 1-2 (1994), 137-47.
}

\footnotetext{
${ }^{8}$ Isaacs, op. cit. (note 5).

${ }^{9}$ F.M. Snowden, The Conquest of Malaria: Italy, 1900-1962 (New Haven: Yale University Press, 2006).

${ }^{10}$ W.F. Bynum, 'Reasons for Contentment: Malaria in India, 1900-1920', Parassitologia, 40,1-2 (1998), 19-27: 21.
} 
international research and attempted to utilise them in specific local contexts. S.R. Christophers, the malariologist who was most influential in conducting research, benefited from the work of Angelo Celli in the Roman Campagna, as well as from Robert Koch's immunity studies on malaria. Within tropical colonies, Malcolm Watson's ideas on the flying radius of the anopheles, from Swellengrebel's work on 'species sanitation', targeting the malaria parasite carriers, reinforced control programmes in India and Ceylon. This juxtaposition between international research and the influence of local human and environmental factors was the main characteristic of malaria research in colonial India.

The focus of medical research on malaria was not surprising, for after cholera, it was the principal cause of mortality in colonial India. It was either constantly prevalent or periodically erupted in epidemic form: in the nineteenth century and between the 1890 s and 1921, it probably took twenty million lives. ${ }^{11}$ In the nineteenth century, Bengal suffered particularly: malaria depopulated entire districts, and state public health policies, and to an extent, popular political movements engaged with its effects. ${ }^{12}$ In the nineteenth century, British Indian medical discourse had relegated malaria-ridden Indians to racial and civilisational degeneracy, beyond the reforming momentum of British imperialism. ${ }^{13}$ Subsequent to the discovery and acceptance of the insect-vector transmission of the disease by Ronald Ross, incremental research in tropical medicine privileged selected sites for research on the control of malaria. Both local specificities and international exchange and co-operation were integral aspects of malaria research, and this paper argues that the paradox of local and international priorities were never resolved in malaria research.

\section{Disease and Locality: Tropical Medicine and the Darjeeling Foothills}

The tea plantations of north Bengal were privileged sites of economic activity in colonial India. Large-scale tea plantations were established from 1856 in Terai and Duars, which were located in the foothills of the Himalayan Darjeeling. In 1900, the combined tea production of Darjeeling, Terai, and Duars exceeded a quarter of India's annual tea export and employed over two hundred thousand workers. ${ }^{14}$ The plantations were reclaimed from forests, reed jungles, and miles of swampy land that had a reputation for malarial fevers. The region was subsequently subjected to several malaria surveys, emphasising the importance of 'location' within both the colonial economy and medical research.

Duars and Terai were well known to travellers and soldiers as dank and febrile territories. In 1866, when the Vicereine Lady Canning stopped in the Terai on her way to

\footnotetext{
${ }^{11}$ Klein, op. cit. (note 1).

${ }^{12}$ Samanta, op. cit. (note 2), 151-77.

${ }^{13}$ Mark Harrison, "Hot Beds of Disease": Malaria and Civilization in Nineteenth-Century British India', Parassitologia, 40, 1-2 (1998), 11-18; see also,

David Arnold, “"An Ancient Race Outworn”: Malaria
}

and Race in Colonial India, 1860-1930', in Waltraud Ernst and Bernard Harris (eds), Race, Science and Medicine (London: Routledge, 1999), 123-43.

${ }^{14}$ Detailed Report of the General Committee of the Indian Tea Association for the Year 1901, (Calcutta: W. Newman and Co., 1902), 350-2. 


\section{The Logic of Location}

Darjeeling, she contracted a fever from which she never recovered. ${ }^{15}$ Arthur Story, a physician employed in the Duars plantation remarked: "talk about "darkest Africa", I think "darkest Hindustan" is pretty nearly as bad'. 16

With the expansion of the plantation economy, the region was transformed both ecologically and demographically. The plantations cleared forests and introduced the flow of immigrant labour, as well as foreign flora. All of the above changed the ecological and demographic characteristics of the region. The labourers were recruited from the impoverished Santhal Parganas and the Chotanagpur districts of western Bengal through agents (sardars), who themselves worked in supervisory positions in the plantations. In north Bengal, unlike in the older established tea plantations in neighbouring Assam, there was no indentured labour: the labourers were legally free to move. In fact, their mobility depended on their ability to repay loans they acquired from the planters or their agents to pay for living expenses. Each community lived in bamboo and thatch huts (coolie lines), next to its sardars. The tea plantations were generally flanked by villages (bastis), settled by tenant cultivators who worked in the plantations in the peak season. Each tea estate also housed a few clerical staff, as well as two to three assistant managers and the manager, whose bungalow was located at the centre of each estate. The size of the labouring population within a tea estate varied from three-to-four hundred to twoto-three thousand in the larger estates.

While Ross's discovery appeared to promise the elimination of anopheline mosquitoes, the dynamic aspects of the locality itself challenged the presumptions of malaria research. In 1902, the Government of India invited the Malaria Committee of the Royal Society to India. Its members included J.W.W. Stephens, who had initially investigated malaria along the Amazon and was a Fellow of the Royal Society, S.R. Christophers, who later became the Director of the Malaria Bureau of India, and C. W.W. Daniels representing the Colonial Office. ${ }^{17}$ Their Indian tour included the capital city of Calcutta, the Duars, and the agriculturally important Punjab. Their findings suggested that although anophelines were responsible for the transmission of malaria, the degree of infection at a given locality was not directly proportional to the total number of anophelines there. In Calcutta, for instance, they found more anophelines than in 'the worst fever districts of Africa'. ${ }^{18}$ Yet none were found to be infected with malaria. ${ }^{19}$ Whereas in the Duars, there were fewer anophelines but the incidence of malaria was very high. ${ }^{20}$ The report highlighted this factor of locality

\footnotetext{
${ }^{15}$ L.S.S. O'Malley, Bengal District Gazetteer: Darjeeling (Calcutta: The Bengal Secretariat Book Depot, 1907), 53.

${ }^{16}$ A.N.J. Story to his mother, Looksan Tea Estate, 14 August 1892, fo. 321, Mss Photo Eur 275, Asia, Pacific and Africa Collections [hereafter APAC], British Library.

${ }^{17}$ H.E. Shortt and P.C.C. Garnham, 'Samuel Rickards Christophers, 27 November 1873-19 February 1978', Biographical Memoirs of Fellows of the Royal Society, 25 (1979), 179-207; see also Samuel Rickards Christophers, 'John William Watson Stephens, 1865-1946, Obituary Notices of Fellows of Royal Society, 5 (1947), 524-40; J.W.W. Stephens
}

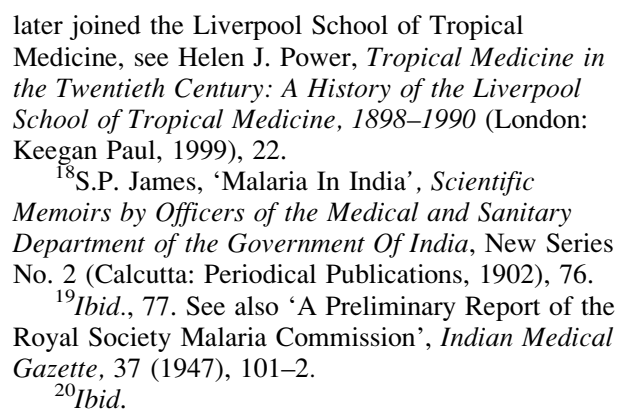


in the phenomenon of 'anophenilism without malaria', concluding that specific breeding places and species of anopheline carriers determined the extent of malarial infection in a locality. ${ }^{21}$ Therefore, the first study on malaria in the tea plantations emphasised the importance of locality in the transmission of the disease, and the Duars region assumed special significance to malaria research.

\section{Vector as Locality: The Mian Mir Debate in Colonial India}

An early experiment at anti-malarial sanitation was conducted between 1902 and 1909 at Mian Mir, a military cantonment near Lahore in the Punjab. The study was conducted by the Malaria Committee of the Royal Society, facilitated by the Government of India and supervised by Stephens and Christophers. The report concluded that anopheline control was not feasible in the area. The conclusions at Mian Mir were responsible for the retreat of anti-malarial sanitation programmes in India through government initiatives for some time. ${ }^{22}$ In official policy and medical discourse, attention shifted towards the human body as the site of prevention.

Sheldon Watts has pointed out that Christophers, as the chief malariologist in India until the mid-thirties, kept the focus of anti-malarial policy in India away from the canals and irrigated rice fields, and instead concentrated on a quinine policy. ${ }^{23}$ Watts argued that direction away from anti-malarial sanitation and towards quinine prophylaxis was motivated by the need to sustain the irrigation policy of the government in British India, particularly the canals in the Punjab, from which private investors in England earned rich dividends and the Government of India reaped the benefits of substantial agricultural revenue.

The irrigation canals were the basis of the agrarian economy of the British Punjab, which was commercialised and greatly expanded under British rule. Two-fifths of the army in colonial India was recruited from the rural peasantry of the Punjab: the loyalty of this army, especially after the Revolt of 1857, was linked to the prosperity of the agrarian economy. ${ }^{24}$ Moreover, as Ira Klein has pointed out, Watts ignored the various studies, especially by Bentley, which drew links between ecological degradation and the incidence of malarial fever in colonial Bengal. ${ }^{25}$ But there was more to the evolving discourse of malaria and the practices of anti- malarial sanitation in India than a simple dichotomy between the 'sanitarian' approach and the 'scientific one' of malarial prophylaxis through the use of quinine. Most malariologists, led by Christophers, emphasised

\footnotetext{
${ }^{21}$ Ronald Ross, who was in the neighbouring Terai while he was in the IMS, also noticed the great paucity of anophelines there. Ronald Ross and L.J. Bruce-Chwatt, The Great Malaria Problem and Its Solution: From the Memoirs of Ronald Ross (London: The Keynes Press, 1988), 194.

${ }^{22}$ For a narrative of the controlled experiments at Mian Mir and the controversy between Ross and Christophers, S.P. James and, indeed, almost all of the Indian medical establishment, see W.F. Bynum, 'An
}

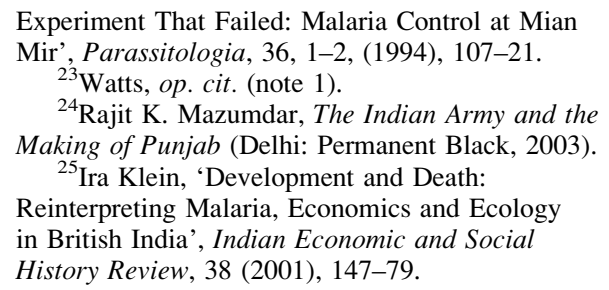




\section{The Logic of Location}

the importance of quinisation. But Ross, who battled the Indian Medical Service (IMS) establishment to focus more on anti-malarial sanitation had also argued that, 'Before practical results can be reasonably looked for, however, we must find precisely (a) what species of Indian mosquito do and do not carry malaria? (b) What are the habits of dangerous varieties? ${ }^{26}$

Therefore, there was no question of indiscriminate implementation of anti-malarial sanitation, even by its strongest advocate. It required detailed research into the habits and breeding places of anopheline mosquitoes, and therefore the question of locality remained. Between 1902 and 1930, malaria research all over the world, as well as in India, demonstrated the enormous variety of types, as well as breeding habits of anopheles, which differed from one terrain to another, making the question of locality a crucial one. By 1913, still convinced that the destruction of parasite-carrying anopheles was possible, Ross presented the successes of the campaigns towards total extermination of malaria in the Panama Canal, in Ismailia in Egypt (near the Suez Canal), and in the Malay Straits. He did not contemplate large-scale prevention in rural areas of either Africa or India. ${ }^{27}$ Years later, Malcolm Watson would point out that Ross had insisted that he was 'misrepresented' and that he had 'never thought and certainly never stated that it would "be possible to exterminate mosquitoes throughout Africa, for instance... always referred... to large towns".,28

In India, Christophers and his colleagues, such as S.P. James and J.A. Sinton, were the most outspoken partisans of quinine prophylaxis as the best mode to control malaria. The strategy of quinisation was complicated: authorities disagreed over whether it could be best used as prophylaxis or as a curative - the supply was far less than the demand for quinine. ${ }^{29}$ The Dutch monopoly over almost ninety percent of the cinchona produced in the world created problems of access. But the quinisation approach was combined with sporadic implementation of anti-malarial sanitation as well as segregation - which were all attempted, in various degrees, in the tea plantations. ${ }^{30}$ British Indian malariologists borrowed theories of transmission and control of malaria from the research conducted in Italy two decades previously, including identifying the 'human factor' in transmission, the use of quinine prophylaxis, and also construction of mechanical screening. Christophers and Bentley's work in the Duars opened a new possibility in identifying the causation and the control of the disease: the collective body of labour congregation in the plantations.

\footnotetext{
${ }^{26}$ Malcolm Watson, 'Malaria and Mosquitoes: Forty Years On', Journal of the Royal Society of Arts, 87,4505 (1939), 485.

${ }^{27}$ Ronald Ross, 'Medical Science and the Tropics', Bulletin of the American Geographical Society, 45 (1913), 435-8.

${ }^{28}$ See Watson, op . cit. (note 26), 483.

${ }^{29}$ The debate was initiated in Italy between Celli and Grassi; while the former advocated its use as prophylaxis, the latter favoured 'radical cure' of patients, by 'curing all cases' so that mosquitoes
}

\author{
would not be infected and the cycle of transmission \\ would break, Snowden, op. cit. (note 9), 50-1. \\ ${ }^{30}$ The segregation of Europeans from native \\ quarters to prevent malarial infection was \\ recommended by the first Royal Society Malaria \\ Committee: Government of Bengal Proceedings, \\ Municipal/Medical, No. 26-28 (December 1903), \\ $\mathrm{P} / 6565$, APAC, 200-1. It became a regular practice in \\ West Africa. See John W. Cell, 'Anglo-Indian \\ Medical Theory and the Origins of Segregation in \\ West Africa', The American Historical Review, 91 \\ (1986), 307-35.
}




\section{Nandini Bhattacharya}

\section{Labour as Location: Malaria Research in the Duars}

In 1906, the British planters in Duars petitioned for a commission to investigate malaria and blackwater fevers in their locality. The Government of India appointed Christophers and C.A. Bentley to investigate malaria and blackwater fever in the region. ${ }^{31}$ Their report linked malaria with the structures of the plantation economy and located the disease in the community of newly immigrant labourers, rather than on local miasmatic influence. This transformed the question of location. Referring to researches on immunity conducted by Robert Koch and by Angelo Celli (in the Roman Campagna), they asserted universal links between malaria with congregations of a labouring population:

We may say that in our researches on malaria we have for some time recognised the almost constant association of labour camps with severe malaria.... It is not the soil disturbance, we believe, but the occurrence of labour camp conditions, or what we shall call for convenience of description THE TROPICAL AGGREGATION OF LABOUR, in association with these enterprises which has given them their evil reputation. ${ }^{32}$

The 'tropical aggregation of labour' or the 'human factor' in the transmission of malaria marked a shift in the significance of location in malaria research. Now the congregative bodies of labourers comprised the location of disease. Although the 'human factor' in malaria that informed the thesis of 'tropical aggregation of labour' was previously described by Koch and Celli, it had particular resonance for immunity studies in industrial sites in tropical countries. The study linked, for the first time in India, epidemiological explanation of malaria to the influx of immigrant labour and the 'factor of non-immune migration' at any industrial site: ports, jute mills, tea gardens, and railway construction sites. ${ }^{33}$ The movement of infected workers made them mobile reservoirs of malaria. ${ }^{34}$ The thesis of the tropical aggregation of labour gained credence through reiteration in national and international forums. In 1929, the League of Nations Malaria Committee carried out an inspection tour of India at the invitation of the Government of India. Christophers wrote the preface to their report. The factor of non-immune immigration at industrial sites was cited as a major cause of the spread of malaria, particularly mines, plantations, and ports. ${ }^{35}$

\footnotetext{
${ }^{31}$ Government of Bengal, Municipal/Sanitation Proceedings Volume, B Proceedings Index, West Bengal State Archive (March 1907), 1; Detailed Report of the General Committee of the Dooars Planters Association for 1908, with Proceedings of Annual General Meeting in 1909 [henceforth Proceedings DPA] (Calcutta, 1911), APAC, ii.

${ }^{32}$ S.R. Christophers and C.A. Bentley, Malaria in the Duars (Simla: Government of India Press, 1911), 2.

${ }^{33}$ Ibid., 3-4.

${ }^{34}$ Ibid., 14.

${ }^{35}$ Christophers and Bentley presented the argument at the Indian Medical Congress in Bombay in 1909. Samanta, op. cit. (note 2), 36. In his preface
}

to the report of the League of Nations Malaria Commission to India, Christophers emphasised again this aspect of malaria in industrial locations. By 1927 , the factor of the tropical aggregation of labour, or the human factor in malarial infection was an accepted scientific theory through reiteration in published work on malaria in India. For instance, see Patrick Hehir, Malaria in India (Oxford: Oxford University Press, 1927), 45-9. The League of Nations Malaria Committee endorsed the theory of non-immune immigration into industrial locations as a principal cause of malaria. See Report of the Malaria Commission on its Study Tour in India (Aug. 23 to Dec. 28, 1929), (Geneva: League of Nations, 1930), 31 . 


\section{The Logic of Location}

In 1923, Christophers, then Director of the Malaria Bureau of India, wrote a report on the prevalence of malarial fever in the Bengal Iron Company's mines at Singhbhum. ${ }^{36}$ He made similar recommendations to those he made in the Duars in 1908, such as the screening of European bungalows, segregation, and the use of quinine as prophylaxis. ${ }^{37}$ By this time, the concept of the tropical aggregation of labour was entrenched. Christophers further refined the theory: that settled workers acquired an immunity to malaria that was not racially inherited but acquired through repeated infections suffered by the newly immigrant labourers and by newborn children and infants. Therefore, even if the spleen rate of a certain area showed a high endemicity of malaria, the adult population was not unduly affected, as they had gone through the process of acquiring immunity through repeated malarial infections. Industrial and plantation sites with immigrant workers acquired new significance as locations of malarial fever. The focus on the body as the location of disease relocated the links between malaria, race, and immunity.

Christophers and Bentley denied that race was significant in the causation of malaria. ${ }^{38}$ Nevertheless, in 1923, Christophers referred to certain 'susceptible races' such as the European staff and the skilled labour (mostly Hindus and Muslims). The unskilled mine workers were 'indigenous, largely aboriginal' and were 'fairly immune to malaria', which came after a period of 'acute infestation' of malaria for about two years - a process he compared to the 'salting of animals in trypanosomiasis'. ${ }^{39}$ In 1926, when the Government of Bengal reported its findings on anti-malarial measures in a tea estate in Duars, it sketched out possibilities of infection very similar to the conclusions reached in the mining areas of Bihar:

If a mixed population of men, women and children who were susceptible to malaria were introduced into such an area, there would in the first instance be an explosive outbreak of malaria amongst the new comers... In a vigorous race, there would be a 'rally' in the individual against the parasite and gradually a tolerance or relative immunity would be developed... A time would come when the only persons not possessing a relative immunity would be newly born children. These would all be intensely affected and would suffer from continuous fever until they either died or gradually acquired a relative tolerance. ${ }^{40}$

Such a conception of immunity from malarial infection that posited distinctions between 'vigorous' and other races led to the conclusion that certain communities were more likely to acquire immunity than others: for instance, the Government of Bengal report of 1926 pointed out 'there are certainly racial differences. Santals, for instance, seem to get immune more quickly than Nepalese, who would appear to possess small powers of immunity production. ${ }^{41}$ Although there was some ambivalence about it, the

\footnotetext{
${ }^{36}$ S.R. Christophers, Enquiry on Malaria, Blackwater Fever and Anchylostomiasis in Singhbhum: Preliminary Investigation into the Conditions on the Bengal Iron Company's Mines at Manharpur (Patna: Superintendent, Government Printing, Bihar and Orissa, 1923).

${ }^{37}$ Ibid., 29.

${ }^{38}$ Christophers and Bentley, op. cit. (note 32), 23.
}

\footnotetext{
${ }^{39}$ Christophers, op. cit. (note 36), 30. See also see S.R. Christophers, 'The Mechanism of Immunity against Malaria in Communities Living under Hyper-Endemic Conditions', Indian Journal of Medical Research, 12 (1924) 273-94.

${ }^{40}$ Report of the Malaria Survey of the Jalpaiguri Duars [hereafter RMSJD] (Calcutta: Bengal Government Press, 1926), vii.
} 
assumption of immunity or partial immunity of certain races to malaria continued to inform British Indian medical discourse. ${ }^{42}$

This was different from the earlier nineteenth-century ideas of racial immunity to fever. In the mid-nineteenth century, David Rennie, in his account of the Bhutan campaign of 1865 , mentioned that the Meches, the pre-colonial inhabitants of the region, were peculiarly immune to fevers. ${ }^{43}$ By linking racial immunity to acclimatisation in a specific locality, Rennie conceived of immunity as both racial as well as locational. This was a general conception among contemporary medical practitioners and colonial ethnologists, such as E.T. Dalton. ${ }^{44}$

This particular link between racial immunity, location, and fever became irrelevant in the twentieth century, by which time the indigenous Meches were pushed out of the region. ${ }^{45}$ In the twentieth century, malaria research retained both racial and locational categories and re-articulated them in the bodies of infected immigrant races. When Patrick Hehir wrote Malaria in India in 1927, he emphasised that 'dark-skinned races, living in malarious regions, possess a relative immunity to malarial infection. This is explicable as an acquired immunity.... ${ }^{46} \mathrm{He}$ quoted Koch to argue that the 'acquired immunity' occurred relatively rapidly in cases where quinine was not used. This emphasis on acquired immunity from malaria reinforced arguments against the adoption of more expensive quinine prophylaxis as well as anti-malarial sanitation in the plantations. This encouraged some planters to explore 'acquired immunity' among the labourers. Immunity studies in malaria, developed out of the theory of tropical aggregation of labour, acquired economic as well as epidemiological implications in the tea plantations. In 1927, when Ronald Ross visited Duars, the chairman of the planters' association wanted research on immunity to malaria: 'I have often felt that it should be possible to create this immunity by some artificial means and thereby hasten on what nature now does so slowly'. ${ }^{47}$ At the same time, the idea of the local continued to appear in multifarious forms. Along with the congregative body of the labourers, malariologists linked transmission to local ecological factors.

\section{Anti-Malarial Sanitation and the Question of Location}

At an institutional level, malaria research in India was initially conducted at the Central Research Institute and was sponsored by the Indian Research Fund Association, (IRFA) set up in 1911. This research was subsidised partly by the Government of India, and

\footnotetext{
${ }^{42}$ Warwick Anderson, 'Immunities of Empire: Race, Disease, and the New Tropical Medicine, 1900-1920', Bulletin of the History of Medicine, 70 (1996), 94-118.

${ }^{43}$ David Field Rennie, Bhotan and the Story of the Dooar War (London: J. Murray, 1866), 347-8.

${ }^{44}$ See Asok Mitra, The Tribes and Castes of West Bengal (Alipore: West Bengal Government Press, 1953), 224.

${ }^{45}$ Subhajyoti Ray, Transformations on the Bengal Frontier (London: RoutledgeCurzon, 2002), 79. The
}

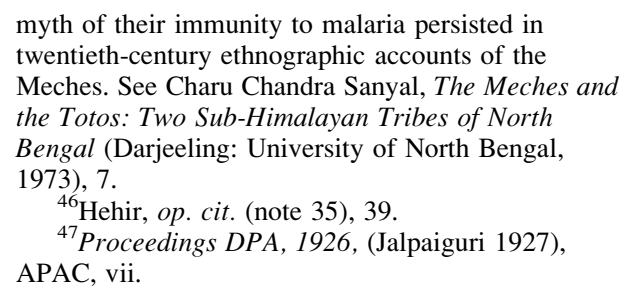
twentieth-century ethnographic accounts of the Meches. See Charu Chandra Sanyal, The Meches and the Totos: Two Sub-Himalayan Tribes of North Bengal (Darjeeling: University of North Bengal, 1973), 7.

${ }^{46}$ Hehir, op cit. (note 35), 39.

${ }^{47}$ Proceedings DPA, 1926, (Jalpaiguri 1927), APAC, vii. 


\section{The Logic of Location}

published the Indian Journal of Medical Research. ${ }^{48}$ The IRFA also solicited private subscription. Besides army cantonments (such as Mian Mir), anti-malarial sanitation was attempted at mines and plantations. The success or failure of any anti-mosquito campaign was understood with reference to local ecological conditions. The Imperial Conference on Malaria in Shimla in 1909, led to the formation of a Central Malaria Committee to direct the course of anti-malarial operations in different provinces. ${ }^{49}$ At the conference, J.T.W. Leslie, the Sanitary Commissioner, pointed out that the Drainage Committee of Bengal had found that local ecological factors determined the extent of malaria. $^{50}$

Officials concluded that "we have little exact knowledge of the distribution of malaria in the country, of the local conditions which favour it, and of the best means to render these causes inoperative. ${ }^{51}$ This concept of 'local knowledge' or this notion of locality was an ambiguous scientific category: identified simultaneously with the vector, the land, and demography. Yet, local knowledge was a powerful motif for colonial governance. In colonial India, local knowledge was both a condition and validation of rule. It became the basis of colonial rule: in terms of the knowledge of local languages, demography, caste, and economic geography. ${ }^{52}$ For the colonial government, any move for sanitary reform had to be based on 'local knowledge':

[We] must recognise the diversity of local conditions in a country which includes numerous communities, castes and creeds and which exhibits almost every variety of climate, temperature, humidity and level of sub-soil water, from the Deltas of Bengal with their steamy atmosphere and dense lush vegetation to the burnt brown hills of the north-west frontier. ${ }^{53}$

This emphasis on locality and local knowledge was such a fundamental element in colonial administration in India that it continued to inform medical research and practice. This administrative prerogative informed British Indian epidemiological theories, which continued to emphasise the agency of local factors in the causation of disease. The tenacity with which the Indian medical establishment perceived India's disease terrain as both distinctive and esoteric, requiring experience and familiarity to be medically understood, demonstrates the persistence of the rhetoric of the 'local' ${ }^{54}$ The insect-vector theory and the subsequent research on malaria reinforced the idea of the importance of 'local' disease factors, such as the diversity in the anopheline species and the variables in their breeding.

Medical professionals in Britain also made the link between local ecology and epidemics in the inter-war years. As J.A. Mendelsohn has pointed out, in the inter-war years medical scientists working on 'bacteriological epidemiology' in Germany and Britain

\footnotetext{
${ }^{48}$ Mark Harrison, Public Health in British India: Anglo-Indian Preventive Medicine, 1859-1914 (Cambridge: Cambridge University Press, 1994), 164.

${ }^{49}$ Ibid., 297.

${ }^{50}$ Government of Bengal Proceedings, Municipal/ Sanitation, No.1-2 (March 1911), P/8686, APAC, 3.

${ }^{51}$ Government of Bengal Proceedings, Municipal/ Sanitation, No. 14-15 (July 1910), P/8419, APAC, 30 .
}

\footnotetext{
${ }^{52}$ Tropical Medicine was one such modality of knowing the 'local', see B.S. Cohn, Colonialism and Its Forms of Knowledge: The British in India (Princeton, NJ: Princeton University Press, 1996), 4-5.

${ }^{53 ،}$ Resolution No. 888-908, Government of India, Education/Sanitation', Indian Journal of Medical Research, 1, 4, (1914), 591-2.

${ }^{54}$ Isaacs, op. cit. (note 5); Harrison, op. cit. (note 5).
} 


\section{Nandini Bhattacharya}

borrowed increasingly from older traditions of epidemiology, as well as using new mathematical models to formulate what he described as 'holistic' and 'non-reductionist' explanations of epidemics. ${ }^{55}$ Helen Tilley has claimed that research on trypanosomiasis in Africa also appropriated a complexity of variables among ecology, insect vector, parasite, and human and animal infection in the inter-war years.

Although malaria research in colonial India both borrowed from and informed the intellectual paradigms of malaria causation internationally, it was in some senses a particularly colonial story. The significance of local environment was a prerogative of colonial rule that had informed British ideas of health, European and native bodies, and colonial policy from the eighteenth century. ${ }^{56}$ In the nineteenth century, this informed the medical discourse of the anti-contagionists. ${ }^{57}$ In colonial India, the recurring alignment of local factors in disease causation through divergent and multiple meanings, including ecological factors, human agency, and the cultural practices of the diseasestricken, had preceded the holistic medicine of inter-war Britain. The constitution of the 'local' differed: it could be located in ecological, cultural, or economic factors. For instance, in the Duars, while planters and officials emphasised the cultural and political factors in the implementation of anti-malarial programmes, medical experts generally focused on the heterogeneity of ecological and environmental factors. So far as malariologists were concerned, the focus of the local shifted to the 'human factor' following the work of Christophers. The colonial government believed that the responsibility for the lack of sanitary reform in India could be attributed to the 'apathy, fatalism, and resentment of interference' of the 'uneducated masses' ${ }^{58}$ Besides reinforcing the paternalism of colonial administration, this engendered a gradualist view of sanitary reforms acquired systematically from the knowledge of the local conditions, linking indigenous people with topography, often used as interchangeable categories. The 'local' in various manifestations remained the paradigm for malaria research in India.

\section{Local Ecology and the Meenglas Experiment}

The multiplicity of local conditions involved in malaria control in the tea plantations was demonstrated in the anti-malarial sanitation project at the Meenglas Tea Estate in Duars. It was owned by the managing agency of Duncan Brothers Limited, a British company. The funds for the Meenglas experiment were paid entirely by the Bengal provincial government. The experiment lasted eight years, beginning in $1917 .{ }^{59}$ The aim of the

\footnotetext{
${ }^{55}$ J. Andrew Mendelsohn, 'From Eradication to Equilibrium: How Epidemics Became Complex after World War I', in Christopher Lawrence and George Weisz (eds), Greater Than the Parts: Holism in Biomedicine 1920-1950 (Oxford: Oxford University Press, 1998), 303-31.

${ }^{56}$ Mark Harrison, Climates and Constitutions: Health, Race, Environment and British Imperialism in India, 1600-1850 (Oxford: Oxford University Press, 1999); see also Richard H. Grove, Green Imperialism: Colonial Expansion, Tropical Island
}

Edens and the Origins of Environmentalism, 1600-1860 (Cambridge: Cambridge University Press, 1996), 427-36.

${ }^{57}$ Mark Harrison, 'Tropical Medicine in Nineteenth-Century India', British Journal for the History of Science, 25 (1992), 299-318.

${ }^{58}$ 'Resolution No. 888-908', op. cit. (note 53), 590.

${ }^{59}$ Government of Bengal Proceedings, General/Sanitation, No. 1-2 (September 1914), P/9375, APAC, 4-9. 


\section{The Logic of Location}

experiment was to prevent the breeding of carrier anophelines in a terrain where the land was cut up by several seasonal streams (jhoras). In the Duars, the seasonality of the streams depended on the terrain: for instance, the ones on the slopes remained dry for most of the year, while the ones closer to the plains were perennial. ${ }^{60}$ Other ecological characteristics of the area were the proximity of jungles, rice fields, and three fast-flowing rivers.

The area under the experiment was three-quarter-mile radius chosen carefully based on the views of Malcolm Watson, whose successful policies in Malaya had shown that the flight of anophelines did not exceed half a mile. However, the local factors of Duars soon became apparent to the surveyors. The three most dangerous local carriers were identified as A. maculatus, A. listoni and A. culicifacies. Unlike the Malayan experience, here the anophelines that inhabited the nearby forests, principally the A. aitkeni, were found to be harmless. ${ }^{61}$ The experiment demonstrated that the underground drainage of streams controlled the breeding of anophelines. It demonstrated that the spleen index of the children and malarial fever could be reduced for a limited period within the controlled area. ${ }^{62}$

In 1925, Bentley, who was now Director of Public Health for the Government of Bengal and who initiated the scheme, reported on the efficiency of sub-soil drainage in reducing the death rate and the fever index. ${ }^{63}$ However, the average overall death rate in the tea estate did not decline during the eight years of the experiment. The spleen index remained 'almost static' from 1923 to $1927 .{ }^{64}$ The final report concluded, 'As regards the actual reduction of malaria, this is a point on which it is very difficult to form an exact opinion, mostly owing to the factor of shifting population. ${ }^{65}$ The indifferent success rate here highlighted the complex political, economic, and environmental factors in anti-malarial sanitation in tea plantations.

One principal problem was the provision of free movement of labourers between plantations. The planters retained the system of free labour because it exempted the plantations from government regulations, such as in neighbouring Assam, where contractual labour had to be examined by medical officials for fitness. The labourers living in the bastis of the north Bengal tea gardens were used in peak times but the management did not assume responsibility for them. The relationship between the tea garden and the basti was one of dependence, suspicion, and even hostility. Tea production relied on the seasonal labour from the bastis, yet every epidemic disease in any plantation was rumoured to have originated first from the bastis. In managerial discourse, the tea garden was the enclave that protected the health of its labourers, as well as the pristine and primitive nature of their cultures. Yet, the economy of production demanded a labour force that would work in the peak seasons and settle outside, to relieve the plantations from welfare measures for them. This paradox was starkly in relief following the Meenglas experiment. The Duars plantations refused to finance large-scale anti-malarial sanitation except for spending a little on spraying

${ }^{60}$ RMSJD, op. cit. (note 40$)$, vi.

${ }^{61}$ Ibid.

${ }^{62}$ Annual Report for the Director of Public Health, Bengal, 1920 [hereafter ARDPH], (Calcutta: s.n., 1922), 14.

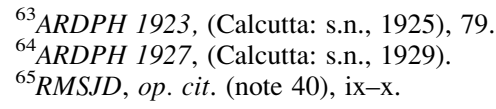

${ }^{63}$ ARDPH 1923, (Calcutta: s.n., 1925), 79.

${ }^{64}$ ARDPH 1927, (Calcutta: s.n., 1929).

${ }^{65}$ RMSJD, op. cit. (note 40), ix-x. 


\section{Nandini Bhattacharya}

kerosene in their streams. ${ }^{66}$ These measures did not prove adequate for the control of malaria. $^{67}$

There was a second local factor crucial to anopheline control in Meenglas: the existence of rice fields close to the plantations and often within them. Most plantations allotted a part of their estates to the labourers where they grew rice and vegetables. The allotments were made to labourers on the condition of work, to keep wages low. They served as instruments of control because the labourers had no tenants' rights here. ${ }^{68}$ This arrangement severely inhibited malaria control. The Meenglas report insisted: 'Rice cultivation should not be allowed'. ${ }^{69}$ The contradictions of malaria control within the plantation economy were fundamental and could not be resolved within the existing administrative and economic structure.

There was a third dimension to this paradox. When anophelines of all varieties were caught at the Meenglas Tea Estate it was found that the three dangerous carriers, $A$. maculatus, A. minimus, and A. culcifacies inhabited the cleared and cultivated areas. A survey of the ecology of malaria in the forested areas of Bengal revealed that forests did not breed anopheline carriers. The clearing of forests and the introduction of tea bushes and rice fields did away with harmless anophelines such as A. aitkeni and A. barbirostri, which were then replaced by the carriers. ${ }^{70}$ Malaria was, in other words, endemic to human habitation and livelihood. This conclusion, from the Meenglas experiment and from other contemporary studies, such as those of Bentley on the links between embankments and malaria, led to the conceptual linking of malaria with modernity and development. ${ }^{71}$ It also contributed to the nationalist critique of British policies in India. ${ }^{72}$

Paddy fields were held to be the cause of malarial fever in the twentieth century, not just in the Duars, but in most of rural India. This was emblematic of the paradoxical relationship between modernisation and malaria in India, where railways and rice fields, the consequence of commercialised agriculture, were seen to cause the disease and yet were impossible to obliterate from the modern Indian landscape. Bentley acknowledged the link between rice fields and malarial fever. ${ }^{73}$ His contribution to the debate was to implement the Italian concept of 'bonificazione'- which according to him embodied 'measures designed for a double purpose, viz. to improve agriculture and improve health. ${ }^{74}$ This shifted the problematic from agriculture to irrigation. In western Bengal, he advocated anti-malarial sanitation not through drainage, but through further inundation through irrigation. Therefore, he avoided making a direct criticism of the development policies of the government and instead suggested a solution that would lead to more, rather than

\footnotetext{
${ }^{66}$ Ibid., 5.

${ }^{67}$ Ibid., 49.

${ }^{68}$ Report of the Royal Commission on Labour in India (London: H.M.S.O., 1931), 384-5.

${ }^{69}$ RMSJD, op. cit. (note 40), 48. The factor of the cultivation of rice in the increase of malarial fever was acknowledged by C.A. Bentley, Malaria and Agriculture in Bengal: How to Reduce Malaria in Bengal by Irrigation (Calcutta: Bengal Secretariat Book Depot, 1925).

70 'Jungle and Malaria in Bengal', Indian Medical Gazette, 63 (1930), 639. See also Bhupendra Mohan
}

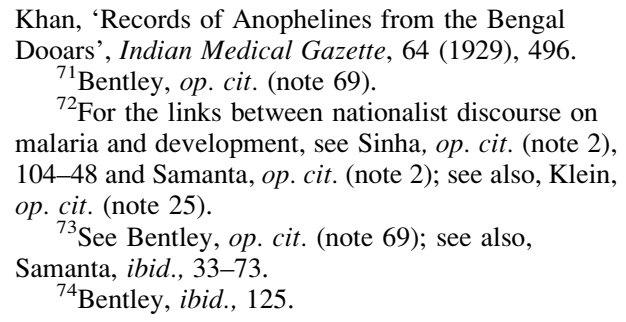
Dooars', Indian Medical Gazette, 64 (1929), 496.

${ }^{71}$ Bentley, op. cit. (note 69).

${ }^{72}$ For the links between nationalist discourse on malaria and development, see Sinha, op. cit. (note 2), 104-48 and Samanta, op. cit. (note 2); see also, Klein, op. cit. (note 25).

${ }^{73}$ See Bentley, op. cit. (note 69); see also,

Samanta, ibid., 33-73.

${ }^{74}$ Bentley, ibid., 125. 


\section{The Logic of Location}

less, investment in irrigation. This strengthened the rationale of the developmental projects of the colonial government. ${ }^{75}$ Therefore, the case for malaria control was laid to rest with the emphasis on rice cultivation. This was ironic, for it had been the call of tropical medicine to render 'a great gift to the human race', to penetrate impenetrable tropical jungles and make them habitable. ${ }^{76}$ Tropical medicine identified this paradox but failed to resolve it.

Almost two decades previously, in a continuation of the acrimonious debate on the failure of the anti-malarial measures at Mian Mir, Ross had alleged both the lack of adequate data and the faulty application of scientific knowledge in the Mian Mir operations. He was convinced that anophelines could be destroyed in any given area, and what remained to be accomplished was to accommodate local variables. ${ }^{77}$ In Meenglas, the malaria surveys were conducted and the entomological studies and the spleen index of labourers in neighbouring tea estates examined. The problem here was the logistic impossibility of extending the area under operation. The experiment at Meenglas (and a similar experiment at the mining sites of Singaran and Topsi in Bengal) demonstrated that eradication of malaria would not be possible in hyper-endemic areas. ${ }^{78}$ The experiment confirmed that while the idea of locality in disease control remained problematic, in administrative terms the category of the 'local' assumed fresh significance. The Public Health Department utilised the lessons of Meenglas to negate the possibility of drainage operations at any cultivated site in the intensely malarial Lower Bengal. This marked the duality of local factors within scientific and administrative priorities. We will next explore the sustenance of this 'local factor' in questions of malaria control in colonial India.

\section{Entrepreneurial Patronage and Malaria Research}

In twentieth century India, medical research and the newly established institutes of public health received financial aid from private entrepreneurs, as well as the Government. The Calcutta School of Tropical Medicine was instituted in 1921 and was funded with donations from the Government of India, the Bengal government and the local Indian elite. ${ }^{79}$ It also received subscriptions from British-dominated jute, tea, and mining industries in eastern India. ${ }^{80}$ This patronage occasionally defined its activities. Initially the

\footnotetext{
${ }^{75}$ For criticisms by the medical establishment of his thesis that flooding, not drainage would solve the problem of malaria in the Bengal plains, see 'Malaria and Agriculture in Bengal', The Lancet, 206 (1925), 926-7. See also 'Some Malarial Problems in Bengal', Indian Medical Gazette, 48 (1913), 112-13.

${ }^{76}$ For the consequences of the commercialisation of agriculture and malaria in Colonial Bengal, see Rajat K. Ray, 'The Crisis of Bengal Agriculture, 1870-1927: The Dynamics of Immobility', Indian Economic and Social History Review, 10 (1973), 244-79.

${ }^{77}$ 'Seventy Second Annual Meeting of the British Medical Association Held at Oxford, July 26th-29th, 1904', British Medical Journal, 2 (1904) 632-5.
} 
Calcutta School began research on kala azar in the tea plantations of Assam. When the planters realised that the Government was to fund a separate research programme on the same disease, they proposed to divert the School's research to malaria surveys. ${ }^{81}$ In Assam, the total production of tea was more than two and a half times that of northern Bengal, involving a heavier cost of labour. But the planters of north Bengal invited the Government to aid research highlighting the 'unique conditions' of the region that they believed were ideal for the study of 'malaria and other obscure tropical diseases. ${ }^{82}$ They discussed funding for a research institute in the Duars, but realising that it would cost around 35,000 to 50,000 rupees annually, opted for a more economical alternative: a 'malarial survey by an expert' from the School, much like the Assam survey. ${ }^{83}$ In 1926, C.K. Strickland, a malariologist of the Calcutta School conducted a preliminary survey in the Duars, as in Assam. ${ }^{84}$ The arrangement between the Calcutta School and the Dooars Planters' Association resulted in several malaria surveys of Darjeeling and the Terai. Until the advent of DDT, the tea plantations continued to be sites of malarial research, providing ideal 'local' qualities for such research. Most studies located the infectivity of anophelines in specific breeding conditions: there was some anti-malarial drainage in one tea estate in Darjeeling. ${ }^{85}$ Others studied comparative causes of epidemics of malaria in hill stations, such as Shillong (Assam) and Kurseong (Darjeeling). ${ }^{86}$ The Terai Planters' Association also funded a survey through the agency of the Calcutta School of Tropical Medicine. ${ }^{87}$

Despite obligatory visits to the 'location', malaria research remained unconnected with any real action on the ground. The logic of location in malaria research was fulfilled within the surveys undertaken in the sites. In 1926-7, when Ross visited the area, he was invited to the annual meeting of the Duars Planters' Association. With typical candour, he pointed out the futility of endless surveys without action; 'I now ask what does the Dooars intend to do? ${ }^{88}$ He received no commitment from the planters. In his preface to the League of Nations Malaria Commission report, Christophers conceded that antimalarial initiatives rarely proceeded from surveys to preventive operations in the tea estates in India:

\footnotetext{
${ }^{81}$ Detailed Report of the General Committee of the Indian Tea Association, 1923 (Calcutta: s.n., 1924), 27.

${ }^{82}$ Proceedings DPA, 1925 (Jalpaiguri: s.n., 1926), APAC, ix.

${ }^{83}$ Ibid., xx; see also C. Strickland, Abridged Report on Malaria in the Assam Tea Gardens Indian Tea Association (Calcutta: Indian Tea Association, 1929).

${ }^{84}$ Although the anophelines of Assam were distinct from those of Duars and Terai, common problems included the existence of rice fields and the cultivation of rice by plantation workers. See also C. Strickland, 'The Mosquito Factor in the Malaria of Assam Tea Gardens', Indian Medical Gazette, Vol. 60 (1925), 60.

${ }^{85} \mathrm{C}$. Strickland, 'Malaria on Ambootia Tea Estate near Kurseong and the success of some anti-malarial
}

operations', Indian Medical Gazette, Vol. 59 (1924), 119-20; see also C. Strickland and H.P. Chaudhuri, 'More on Hill Malaria', Indian Medical Gazette, Vol. 71 (1936), 267-9.

${ }^{86} \mathrm{C}$. Strickland, 'Notes on Malaria in the HillStations in or near the Eastern Himalayas'. Indian Medical Gazette, Vol. 59 (1924), 549-50. Strickland emphasised 'engineering works' over 'personal prophylaxis'.

${ }^{87}$ C. Strickland and K.L. Chowdhury, Blackwater Fever and Malaria in the Darjeeling Terai (Calcutta: n.p. 1931), 3; D.N. Roy and K.L. Chowdhury, 'The Parasitology of Malaria in the Darjeeling Terai', Indian Medical Gazette, 65 (1930), 379-80.

${ }^{88}$ Proceedings DPA, 1926 (Jalpaiguri, 1927), APAC, xviii. 


\section{The Logic of Location}

At present, after a 'survey' and recommendations, nothing very much often follows, largely because it is then left to the manager of such estate to do what he can, whereas the proper course would be to engage a suitable man to reside on the area and see to the carrying out of whatever was possible. ${ }^{89}$

Why this lack of antimalarial action within the region by the planters? In administrative terms, the main hindrance to the efforts on the part of the tea estates to engage in anti-malarial operations was the ad hoc nature in which they operated and the short term incentives involved, where the managers of the estate were personally responsible for the finances of the tea estate. Any long-term investment in a tea estate would detract from immediate profits and targets and thereby from the commission received by them. Strickland pointed this out in his report while suggesting that the managers not be made responsible for the anti-malarial sanitation work. ${ }^{90}$

Some initiatives were undertaken from England as well. In 1930, the Ross Institute in Putney, which was supported partly by the India Tea Association in London, opened a branch in Shillong, in north-eastern India. However, the drainage measures undertaken in India under the supervision of the Ross Institute were concentrated in the tea estates of Assam, where the large managing agencies had contiguous territories and several tea gardens under their control. ${ }^{91}$ The Duars and Darjeeling regions remained overlooked despite the shortage of quinine during the Second World War, which aggravated the problem of malaria in the plantations of north Bengal. ${ }^{92}$ Mortality from 'fever' remained the single largest cause of death in the plantations. ${ }^{93}$

The emphasis on productivity and possibilities for entrepreneurial patronage did not translate into sustained anti-malarial sanitation in the Duars and Terai plantations. Local characteristics differentiated the Assam tea plantations from those in the Darjeeling foothills. Firstly, Assam was geographically more distant from the labour recruiting districts of western Bengal and Bihar. Recruitment of labour was expensive in Assam compared to Duars and Terai, so it made better sense to make arrangements for the healthcare of the working population of the Assam plantations. This did not necessarily mean welfare of the labourers, as the Assam plantations had a darker reputation for coercion and illtreatment of workers by the planters and sardars and much of the funds were usurped by them. ${ }^{94}$

Secondly, the average acreage of tea estates in Assam was larger than in north Bengal, and the gardens there were owned in contiguous territories by British managing agencies, all of whom were members of the British-dominated Indian Tea Association.

\footnotetext{
${ }^{89}$ Report of the Malaria Commission, op. cit. (note 35), 26.

${ }^{90}$ Strickland, op. cit. (note 83).

${ }^{91}$ The Ross Institute of Tropical Hygiene, London School of Hygiene and Tropical Medicine, Supplementary Report to the Indian Tea Association, 1934, Mss Eur/F174/1212, APAC; see also Percival Griffiths, The History of the Indian Tea Industry (London: Weidenfeld and Nicolson, 1967), 357.

${ }^{92} \mathrm{~B}$. Chatterjee, 'Treatment of Malaria in the Present Emergency', Indian Medical Gazette, Vol. 77 (1942), 701-2.
}

\footnotetext{
${ }^{93}$ D.V. Rege, Labour Investigation Committee: Report on an Enquiry into Conditions of Labour in Plantations in India, (Dehli: Manager of Publications, 1946), 91.

${ }^{94}$ The recruitment of Duars labourers cost ten per cent of those in Assam in 1894; J.C. Arbuthnott, Report on the Conditions of Tea Garden Labour in the Duars of Bengal, in Madras, and in Ceylon (Shillong: s.n., 1904), 4; see also Nitin Varma, 'Coolie Acts and the Acting Coolies: Coolie, Planter and State in the Late Nineteenth and Early Twentieth Century Colonial Tea Plantations of Assam', Social Scientist, 33 (2005), 49-72.
} 
In the Duars and Terai, on the other hand, the estates were smaller in size, about a quarter of which were under Indian management. The Indian planters felt excluded from and resented the British-dominated Indian Tea Association. They formed their own, much smaller organisation, the Indian Tea Planters' Association. Moreover, several Indian planters owned jotes, tenanted agricultural land for rice cultivation often next to the tea estates, which would have been adversely affected by antimalarial drainage operations. Finally, since the tea estates in north Bengal recruited casual basti labour, the very system depended on labourers who would cultivate rice in the neighbouring paddy fields and work in the plantations as well. Therefore, although public health officials and medical experts from Calcutta and London pointed out the advantages of investment in anti-malarial sanitation, the structure of the plantation economy in Duars and Terai inhibited any large-scale investment in antimalarial sanitation.

\section{Conclusion:}

\section{Where Were the Tea Plantations Located?}

The logic of location emerged within malaria research as an attempt to accommodate local variability in the causation of the disease. However, this also exposed the tension between scientific research, entrepreneurship, and local realities. The Darjeeling foothills and the plains of Terai and Duars were the sites of studies in tropical medicine conducted from London and Calcutta. These led to the identification of causation of malaria in industrial locations all over India, with the factor of non-immune immigration and the tropical aggregation of labour. At the same time, these local sites were exposed to the confluence of metropolitan scientific ideas. The malaria control experiment that was started at the Meenglas Tea Estate borrowed from the knowledge of anophelines and preventive measures developed by Ronald Ross (the anopheline count per head of the population factor in infectivity) and Malcolm Watson (subsoil drainage), and sought to re-examine their theses in that locality. Thus, the tracts of Duars and Darjeeling Terai were at once connected to the entire tropical world and its diseases and to the world of metropolitan and colonial tropical medicine. In doing so, although malariologists failed to specify links between locality and disease in clear terms, and the ambiguities of the 'local' in terms of ecology, demography, and race confounded anti malarial policy, the logic of location continued to be the focus of such surveys.

The Darjeeling foothills were not unique in this respect. Colonial realities informed, complicated, and challenged the inadequacies of the contemporary medical theories of the metropolis. Twentieth-century medical research is seen to have become inclusive and holistic as it ventured from the laboratories to the field. ${ }^{95}$ However, as this paper has shown, within scientific research the incorporation of the problematic of location

\footnotetext{
${ }^{95}$ Helen Tilley, 'Africa as a "Living Laboratory": The African Research Survey and the Colonial Empire: Consolidating Environmental, Medical and
}

Anthropological Debates, 1920-1940' (DPhil dissertation: University of Oxford, 2001), 181-97. 


\section{The Logic of Location}

or of the 'field' did not necessarily lead to incorporating the problems of the localities. The prevention of malaria was also situated within this rhetoric of the local. Contemporary research on conditions, such as the hospitability of the different terrains to particular sub-species of the vector anophelines, merged seamlessly with concerns over the peculiarities of labouring populations within the tea plantations and outside them, at the bastis all framed in a set of local conditions.

The rhetoric of the local was used in two different ways. So far as the workers were concerned, the planters generally claimed that quinine prophylaxis could not be administered effectively because the workers were resistant to it. They also insisted that the local government should not interfere with the management of disease within the plantations. Instead, the 'close' knowledge of the labourers and their customs, and the knowledge of local conditions that was the staple of management discourse on the tea estates (at least until a communist-led labour movement dented it substantially after 1946), was presumed to have entitled them to be the guardians of labour welfare. The announcement of the planters' spokesman, W.L. Travers, after the visit of the Royal Commission on Labour to the tea estates is representative of their gradualist and paternalist approaches to reform in health infrastructure within the plantations:

Many of their racial and religious customs tend to impede the work of health improvement and welfare, and therefore it is of great importance that all measures for their uplift in any direction should be under the control and direction of persons who really know and understand the customs, traditions and habits of these aboriginal people. ${ }^{96}$

On the other hand, the idea of 'species sanitation' in tropical medicine provided a new dimension to the colonial understanding of the 'local', in terms of 'expert' knowledge, of the entomologists, malariologists, and parasitologists.

Yet the experts, planters, and local administrators also formed collaborations for conducting malarial experiments in the plantations. The Planters Association at Duars highlighted the unique local conditions when asking the government to fund malaria research in the Duars. This appeal was partly rhetorical: the planters' associations generally sought to shift pecuniary responsibility for any research or sanitary works to the government. Nevertheless, the distinctiveness of the region and the knowledge of local conditions gathered through colonial and managerial discourses did contribute to the knowledge of tropical medicine.

The sub-Himalayan tea plantations were an important site of exploration for new ideas and experimentation in methods of anopheline control. At the same time, the political economy of the plantations highlighted a complex set of factors that inhibited both anti-malarial sanitation as well as systematic and extensive use of quinine prophylaxis within the tea plantations. Some European medical officers within the plantations made isolated attempts at destruction of the anopheline breeding sites within a decade of the discovery of the mosquitovector transmission by Ross. ${ }^{97}$ Some managers made similar attempts in the 1920 s and 1930s. ${ }^{98}$ However, the region itself did not experience

\footnotetext{
${ }^{96}$ Proceedings DPA 1929 (Jalpaiguri: s.n., 1930), APAC, $x$.

${ }^{98}$ Strickland, 'Malaria on Ambootia Tea Estate',

97'The Campaign against Malaria in the Duars', op. cit. (note 85), 119-20.
}

The Lancet, 172, 4429, (1908), 174. 


\section{Nandini Bhattacharya}

any sustained anti-malarial measures and malaria continued to kill the labouring population of the tea gardens. The logistics and structure of the plantation economy could not accommodate any enduring system of malarial prevention.

\section{Acknowledgement}

The author is grateful to the Wellcome Trust for funding the research for this article and wishes to thank Mark Harrison and Anne Hardy for comments on an earlier draft. 